\title{
Adesão ao Trabalho Jornalístico: uma reflexão sobre labor em diálogo com perspectivas da Sociologia das Profissões
}

\author{
Journalistic Adherence to Work: \\ a reflection on labor according to Professions \\ Sociology prospects
}

\begin{abstract}
Robson Dias I robsonico@gmail.com Doutorando em Comunicação, sob orientação do $\operatorname{Prof}^{\circ}$ Dr $^{\circ}$ Luiz Martins da Silva, no Programa de Pós-Graduação da Faculdade de Comunicação da Universidade de Brasília (PPGFAC/UnB). Vinculado aos projetos de pesquisa credenciados no CNPQ: A ideia do pós-Jornalismo (20102013) e O Jornalismo como Teoria Democrática (2006-2010).
\end{abstract}

\begin{abstract}
Resumo: Analisamos alguns elementos constituintes da profissão de jornalista e possíveis contrastes com os modelos analíticos apresentados pela Sociologia das Profissóes em busca de níveis de adesão ao trabalho jornalístico. No texto, a relaçáo do jornalista com o labor é classificada em quatro categorias como sendo: sacerdócio (missão a ser cumprida); negócio (venda da mão-de-obra no mercado de trabalho); profissão (trabalho especializado com uma identidade específica); e emprego (trabalho apenas remunerativo sem vínculo identitário). O intuito é o de um breve panorama sobre as conceituaçóes e modelos analíticos que propiciem o entendimento da especialização do trabalho jornalístico. Abordamos a relação do jornalista com o trabalho utilizando também as tipologias: vocação e trabalho; profissão e emprego; sacerdócio e negócio, da Sociologia das Profissóes.
\end{abstract}

Palavras-chave: Jornalismo; Profissão; Sociologia das Profissóes

\begin{abstract}
We review some elements of the journalistic profession and possible contrasts with the analytical models presented by the Sociology of Professions seeking levels of adherence to journalistic work. In the text, the relationship with the journalist's work is classified into four categories as: priesthood (mission to be fulfilled); business (sale of hand labor in the labor market); profession (skilled labor with a specific identity) , and employment (only remunerative work without bond identity). The purpose is a brief overview of the concepts and analytical models that provide an understanding of the specialization of journalism. We discuss the relationship with the journalist's work also using typologies: work and vocation, profession and employment, and business priesthood, Sociology of the Professions.
\end{abstract}

Keywords: Journalism; Profession; Professions Sociology. 


\section{Ponto de partida: contextualizando o Inato e o Habitus}

Neste artigo, analisaremos alguns elementos constituintes da profissão de jornalista e possíveis contrastes com os modelos analíticos apresentados pela Sociologia das Profissóes. Nosso ponto de partida está ancorado no conceito de Habitus, de Bourdieu (1998), pois consideramos que o mesmo, ao considerar que o ator social se define por seus gostos e pelo seu estilo de vida, pode auxiliar na compreensão do quadro de escolha pelo curso de Jornalismo e pela profissão de jornalista. Desde este ponto de vista, a escolha profissional pode vir não só de uma lógica estratégica, mas da associação de subjetividades de cada indivíduo. Esta relação evidencia uma compatibilidade do indivíduo com uma identidade profissional.

Na visão de Stoque (2007), o Jornalismo é mais do que profissão. É paixão. Quando se decide seguir essa profissão, é preciso ter consciência da sua importância. Para o autor, Jornalismo é paixão para aqueles que percebem o papel social da profissão. E exercer a profissão é acreditar na possibilidade de transformar o cotidiano de quem está a sua volta.

Já para Folquening (2002, p. 106), na opção pela carreira de Jornalismo, o estudante conta mais com uma imagem idealizada (ou romântica) da profissão do que com o anseio pela estabilidade econômica. Os estudantes apontam a possibilidade de desempenhar papel fundamental em esperadas mudanças sociais e capacitar-se para o exercício da cidadania ou para mobilização das massas.

Neste aspecto, Lago (2002) identifica a existência de um Ethos Romântico, no Jornalismo, que deve ser realizado sob o signo da paixão e do envolvimento. Esse Ethos seria um conjunto de disposiçôes, percepções e valoraçóes que jornalistas têm de si e do mundo. Para a autora, o Ethos jornalístico resgata o comprometimento do sujeito (jornalista) e se dá em relação à profissão em si, que se confunde com uma missão a ser realizada.

Lago (2002) ressalta que a característica do jornalista de se engajar em uma missão faz parte do Ethos do Jornalismo. Por mais que a escolha por uma profissão seja pessoal, a autora enfatiza a associação entre uma subjetividade individual e uma identidade profissional coletiva. Desta forma, o indivíduo adere ao grupo profissional por um critério vocacional.

A partir do quadro exposto, passaremos ao estudo de tópicos da Sociologia das Profissôes, ramo específico da Sociologia, que trata da relação do indivíduo com o labor. Analisaremos a inserção do jornalista no meio profissional, além da aplicação de sua força de trabalho como uma missão (engajamento vocacional, missão social) ou como negócio (engajamento profissional, venda da mão-de-obra no mercado de trabalho).

\section{Vocação e trabalho}

A vocação, como uma propensão natural ou inata, do indivíduo para uma profissão tem relação direta com a realização das tarefas de trabalho. A visão social sobre o labor mudou com o advento do Capitalismo (século $\mathrm{XV}$ ), sendo institucionalizada no processo que vai da Reforma Protestante 
(século XV) à Industrialização (século XVIII). A vocação por um ofício antes desse período (século XV ao XVIII) era inspirada no referencial medieval de “expressão do amor ao próximo" (SOUSA, 2002, p. 8). Assim, a divisão do trabalho tinha um acordo mútuo entre os indivíduos de que trabalhassem uns pelos outros para suprir suas necessidades básicas.

Com a Reforma Protestante, o trabalho deixou de ser uma forma de manifestação do amor ao próximo e de subsistência para se tornar um instrumento de reverência à própria divindade por meio do exercício das aptidóes dadas por Deus. Para Weber (1994, p. 53), ser aceito por Deus não era algo vinculado à superação da moralidade secular pela negação do prazer, mas sim pelo cumprimento das tarefas do século com competência, atividades impostas ao indivíduo pela sua posição no mundo. Achava-se que este empenho estaria ligado à vocação.

$\mathrm{O}$ pensamento então vigente era de que o homem nasce com dons e está predestinado a um propósito na Terra. E de que o trabalho era uma característica inerente ao homem. Desta forma, surgiu a compreensão de que o labor era uma virtude dada por Deus (a ser desenvolvida), além de ser uma obrigação (a ser cumprida).

A vocação em relação ao trabalho era baseada no entendimento de predestinação do homem e seus dons. No século XV, Martinho Lutero designou o exercício dos dons como o caminho para a salvaçáo, principalmente baseado em textos bíblicos do Novo Testamento.

Weber (2001), em A Ética Protestante e o Espírito do Capitalismo, utiliza o termo "espírito do capitalismo" como força motriz da sociedade emergente propensa à acumulação de riquezas, à dedicação ao trabalho e ao consumo. Para o autor, o labor passou a ser considerado como uma atividade confessional. Trabalhar era exercer os dons que Deus deu ao homem, como um cumprimento da missáo humana na Terra.

O vocábulo "sacerdócio", em sentido dicionarizado, significa exatamente: "missão" ou "profissão honrosa". Com o Protestantismo, o trabalho secular também foi entendido como algo confessional, sacerdotal. Desta forma, os cristãos se sentiram liberados pelo próprio Deus para trabalhar em outras atividades consagrando aquele serviço à divindade.

Nesta época, houve claramente a aceitação de papéis sociais vinculados ao labor. Uma nova divisão do trabalho e o acúmulo de capital foram incorporados à Ética Cristã. Tais mudanças afetaram os meios de produção e as relaçôes capitalistas vigentes. Sobre estes acontecimentos, Weber (1985) ressalta que

O puritano queria tornar-se um profissional, e todos tiveram que segui-lo. Pois quando o ascetismo foi levado para fora dos mosteiros e transferido para a vida profissional, passando a influenciar a moralidade secular, fê-lo contribuindo poderosamente para a formação da moderna ordem econômica e técnica ligada à produção em série através da máquina, que atualmente determina de maneira violenta o estilo de vida de todo individuo nascido sob esse sistema (WEBER, 1985, p. 131). 
Desta forma, durante o século XV até XVIII, a ideia de trabalho foi impregnada pela noção de missão ou sacerdócio. Mais tarde, durante o período de Industrialização, o trabalho passou a ser vinculado aos meios de produção e foi separado do pensamento cristáo. A lógica empirista da Ciência Moderna fez a ideia de vocação perder sentido. O pensamento crítico do método científico levou o homem a conhecer a realidade de outra forma. Assim, o trabalho foi absorvido por uma lógica de sentido teórico/prático. Perdeu sua vinculação à noção de sacerdócio, ou seja, ao aspecto estritamente confessional.

No fim do século XVIII, a ciência se vinculou à burguesia industrial e passou a produzir conhecimento aplicado aos empreendimentos capitais. A universidade organizou os saberes específicos em campos e se impôs como ambiente de alta qualificação em formação profissional.

A partir desse contexto, a industrialização e o surgimento das zonas urbanas propiciaram a instauração da Sociedade de Massas (ORTEGA Y GASSET, 1992) como configuração sociopolítica. Os indivíduos passaram a integrar vários agrupamentos sociais. As relaçóes entre os grupos passaram a ser mediadas pela imprensa.

A Revolução Industrial, na Europa e nos EUA, além do aproveitamento de um vasto público alfabetizado, ávido por informação e por distração, fez crescer as tiragens dos diários e cair o preço do exemplar. A partir do início do século $\mathrm{XX}$, a imprensa deslanchou como negócio. Criaram-se grandes conglomerados e redes: a imprensa passou por uma crise de crescimento e de ética, apresentando problemas de sensacionalismo, falsificação de informaçôes e subserviência política. Paralelamente a este processo do Jornalismo, a identidade dos jornalistas (profissional e ética) também passou por metamorfoses (RIBEIRO, 2001).

A imprensa, com a ascensão da burguesia industrial, tornou-se palco de luta ideológica e difusão dos ideais de livre comércio e produção. A presença da publicidade nos jornais instituiu uma função particular que obrigava a delimitação de uma zona de neutralidade, imparcialidade e objetividade nas publicaçóes. Para Mattelart e Mattelart (1999, p. 23-37), os países industrializados da Europa e América passaram a influenciar a estruturação das profissões dos países em desenvolvimento. No Jornalismo brasileiro houve a consolidação de um modelo híbrido com características de dois referenciais de trabalho: o Jornalismo Opinativo (referencial europeu) e o Jornalismo Informativo (referencial americano).

\section{Trabalho Jornalístico: sacerdócio ou negócio}

De acordo com Steinberger (2000, p. 179), ter dois referenciais técnicos em Jornalismo acarreta práticas contraditórias no seguinte aspecto: enquanto os norte-americanos adotam a concepçáo de que a imprensa é um negócio, os europeus vêem a profissão como um sacerdócio. Para a autora, boa parte dos conflitos éticos no campo jornalístico origina-se da dificuldade de conciliar esses opostos.

A socióloga Paccola (2003, p. 78) entende que, durante a gestão do referido jornalista, na década de 50, aconteceu uma das mudanças mais importantes no jornalismo brasileiro, tendo como modelo os jornais norte-americanos. Para a 
autora, os americanos prontamente reconhecem que produzir um jornal diário é um negócio. Já os europeus e os latino-americanos gostam de falar da sua profissão como se ela fosse um sacerdócio. A doutrina dominante à qual a autora se refere diz respeito ao jornalista Danton Jobim em relação ao Jornalismo Opinativo que regia as relaçóes de trabalho antes da chegada do pressuposto da objetividade com a revolução empresarial na área que fez da imprensa um negócio.

Na visão de J. Ribeiro (2001), o Jornalismo foi até comparado ao púlpito. Fernando Pessoa escreveu num jornal que a religião e o Jornalismo são as únicas forças verdadeiras; o Jornalismo é um sacerdócio porque tem a influência religiosa de um sacerdote. Essa tradição do jornalista boêmio, criativo, altamente vocacionado e um tanto subversivo perdura até hoje no imaginário da sociedade, sendo elemento inspirador de crescentes contingentes de jovens que procuram a profissão. No entanto, o autor destaca que instaurou-se uma crise de identidade desde que essa imagem heróica do jornalista se viu massacrada pelas empresas: o profissional viu-se ferido em seu íntimo, e sua atividade sofreu uma metamorfose semântica. $\mathrm{O}$ jornalista deixou de ser aquele que milita no Jornalismo para tornar-se aquele que trabalha num jornal.

O escritor e jornalista Ruy Barbosa viveu essa crise de identidade, além do confronto desses dois padrôes de engajamento na profissão. L. Ribeiro (2004) revela que, no início do período republicano, com o declínio do Jornalismo de grandes causas, que já não correspondia às expectativas de debates sobre problemas mais imediatos da vida urbana, Ruy Barbosa sentia-se deslocado ao dividir espaço com gêneros informativos e publicitários, organizados numa paginação sustentada por manchetes chamativas, ilustraçóes e outros recursos voltados para a atração do público.

\section{Amador x Profissional}

O pressuposto de objetividade trouxe o profissionalismo à atividade jornalística. Com a especialização do labor, divisão do trabalho e produção de bens noticiosos pela imprensa, emergiu a institucionalização do jornalismo como profissão, nos moldes que conhecemos hoje. O referencial de Jornalismo Literário passou a ter status de amador e incompetente, em vista do referencial de Jornalismo Informativo, dito profissional e competente.

Mendes (1997, p. 71) acredita que os jornalistas mais velhos, do Jornalismo Literário, se colocam como "anti-profissionais", por não aceitarem as demandas do mercado noticioso, padronização da informação e produtos noticiosos. Enquanto que os dito profissionais (modelo de Jornalismo Informativo) buscam monopolizar a qualificação de "profissional modelo" como uma espécie de violência simbólica, na qual quem corresponde ao modelo é profissional; e quem não, é amador.

\section{O contexto brasileiro}

A força do jornalismo brasileiro está baseada principalmente na institucionalização da atividade jornalística em acordo com seu aspecto legal, o que contribui para a autonomia do campo e o monopólio dos processos de 
produção na área pelos membros constituintes do campo, de acordo com Mendes (1997). Para o autor, o Jornalismo, no Brasil, não pode ser considerado uma profissão fraca.

Em relação à analogia de Mendes (1997) à tipologia de Profissáo Forte, construída por Freidson (1996), podemos identificar que, no contexto brasileiro, o Jornalismo emergiu como profissão forte a partir do advento do referencial de objetividade, nos anos 60 . Nesta fase, surgiram os planos de ensino dos cursos de Jornalismo e de Comunicaçáo Social (com habilitação em Jornalismo), a segmentação do mercado com o registro/expedição de carteiras de trabalho e a regulamentação da profissão.

Entretanto, mesmo o novo paradigma de Jornalismo Informativo tendo se tornado hegemônico, não conseguiu extirpar as práticas de Jornalismo Opinativo da cultura profissional. A coexistência destes referenciais ainda é percebida na formação profissional nos cursos universitários.

Folquening (2002) estudou a consciência dos estudantes de Jornalismo sobre o humanismo inerente à atividade jornalística. Uma de suas entrevistadas evidencia bem o conflito de dois referenciais de jornalismo (Jornalismo Opinativo e Jornalismo Informativo) já no curso de graduação:

alguns professores que falam de ter emprego, de que o importante é saber fazer bem as coisas para encontrar um lugar no mercado de trabalho. Tem outros que parecem achar que o jornalismo é igual a uma igreja que vai salvar a humanidade, que a gente tem que saber tudo e entender de tudo para resolver os problemas do mundo inteiro (FOLQUENING, 2001, p. 138).

Essa fala do estudante mostrada por Folquening (2001) evidencia certa ambiguidade do perfil do jornalista que, ora oscila para a intervenção social (1), ora para a mera aplicaçáo da mão-de-obra frente a uma demanda do mercado de trabalho (2).

A dualidade no perfil do jornalista brasileiro é inerente à categoria profissional. Para Senra (2002, 1997, p. 14), por ser uma profissão eternamente "candidata”, sem os contornos originários de uma autêntica atividade profissional, a identidade profissional do jornalista padece de uma ambiguidade, por assim dizer, "histórica". Para a autora, esta ambiguidade tem presidido o auto-reconhecimento do profissional e talvez esteja igualmente na origem da necessidade recorrente de acentuar as linhas de um perfil por si mesmo pouco definido.

De acordo com a legislação brasileira, as empresas de comunicação não têm que ser necessariamente dirigidas ou gerenciadas por profissionais da área de Jornalismo ${ }^{1}$. A partir desse fato, Mendes (1997) esclarece que o controle das atividades jornalísticas na divisão do trabalho não é privativo de jornalistas. Para o autor, os jornalistas não têm o controle total da notícia como produto. Apesar de a produzirem, os jornalistas não são donos inteiramente de seu trabalho e parecem saber disso exatamente por sustentar o comportamento de evocar para si certo "glamour". Por mais que assinem as matérias (direito autoral), padecem de poder sobre elas (direito patrimonial). 
Mendes (1997, p. 77-80) destaca que esses aspectos contraditórios do mundo profissional do jornalismo parecem criar um clone do que a profissão é para dissimular o que ela gostaria de ser, onde deseja chegar. Para o autor, sobre um palco onde a característica principal do texto encenado é a emoção, a imprensa lança mão do sensacionalismo, da tragédia cotidiana, da construção de uma agenda nacional, do debate comprometido, da denúncia; e investe-se da condição de porta-voz da insatisfação popular. Assim, estabelece um papel social e uma identidade para si, o que coloca a profissão com determinado status no conjunto das outras. Ainda na sua visão, existe uma necessidade e uma atração do glamour que a profissão exerce sobre os que nela trabalham. Ao lado da missão do ser jornalista, do fazer jornalismo, observa-se a emoção do mostrar-se jornalista.

As profissóes têm força no meio social quando combinam dois fatores, segundo Mendes (1997): a capacidade de criar seus próprios problemas para depois desenvolverem o conhecimento abstrato para solucioná-los (1); a capacidade de monopolizar o desempenho de uma atividade especializada para a qual há uma demanda externa vinda da sociedade (2)

A imprensa se institucionalizou como negócio ao reivindicar a importância do trabalho dito profissional. Segundo Mendes (1997), a partir do pressuposto de objetividade, a ênfase sobre a técnica impôs "uma aura em torno da profissão que evidencia como legítimo só a prestação de serviço com o intuito de informar objetivamente". Para o autor, a atividade jornalística foi como um sacerdócio para geraçóes. Era um meio de expressão e circulação de ideias na sociedade. A influência do processo de profissionalização e a instauração de um mercado noticioso contribuíram para a contextualização do trabalho jornalístico como ferramenta de um meio produtivo.

Se havia uma relação do jornalista com o trabalho de forma religiosa e cívica, passou a existir um elo de ordem funcional e materialista. Nesse sentido, tomemos a discussão da atividade jornalística na perspectiva profissão ou emprego.

\section{Jornalismo: Profissão ou Emprego}

A Sociologia das Profissões ${ }^{2}$, ou Sociologia das Ocupaçôes, distingue o termo profissão e emprego ${ }^{3}$. Esses conceitos serão utilizados apenas para visualizar a estruturação da carreira jornalística. Embora não seja nosso objetivo, no presente artigo, esgotar questionamentos sociológicos desses itens. Cremos ser importante discorrer acerca da relação entre jornalista e labor. Tal relação incorre em diferentes tipologias e formas de adesão ao trabalho.

Segundo Lattman-Weltman (1992, p. 96), os tipos podem ser definidos em função de diferentes formas de se auto-avaliar em termos de posicionamento ocupado em hierarquias de prestígio e em termos de remuneração relativa obtida. Assim, ao se pensar em diferentes tipos, podemos ter a presença e ausência de características de cada tipologia e sua perspectiva. Isto se deve, entre outros fatores, a propriedades de pertencimento ao campo jornalístico (emprego carreira, profissão, ofício). Na maioria das vezes, essas características existem enquanto potencialidade que, na prática, podem se mostrar até mesmo como auto-excludentes. Desta forma, ser "empregado" não significa 
necessariamente ter acesso à "carreira” ou à prática do "ofício", e pode mesmo significar a não-efetivação da "profissão".

Lattman-Weltman (1992) identifica tipos de jornalista que se diferenciariam por fatores particulares relativos ao investimento no ofício de trabalhar numa empresa jornalística. Os fatores que os diferenciam são:

1) ser empregado, mormente como assalariado (e não faz, no caso, muita diferença se como "free lancer"), em uma empresa (seja esta pública ou privada);

2) ter acesso (ao menos potencial) a uma carreira, delimitada, a princípio, pela existência de hierarquias formais e informais num "mercado interno de trabalho" (a redação), informais no mercado de trabalho como um todo, e até mesmo fora deste (em ramo próximos, tanto em termos mais técnicos, como publicidade, quanto em termos sociais mais abrangentes como a politica por exemplo);

3) poder ser um profissional, ou seja, um trabalhador de algum modo qualificado e (talvez de modo mais decisivo ainda) juridicamente especificado para o desempenho de tarefas consideradas de interesse público e que dizem respeito a um ideal de funcionamento da sociedade e da ordem política, mais especificamente;

4) e, finalmente, ter acesso (mais uma vez, ao menos potencialmente) ao aprendizado empirico e ao desempenho de um ofício que oferece possibilidade de satisfação estética (ou lúdica) e de vivência de experiências diversas e não totalmente previsiveis (Ibidem).

A Sociologia das Profissóes entende que não há profissóes com conhecimentos simplórios ou complexos. Não entraremos nessa demonstração em relação aos saberes em jornalismo. Em apreço, trabalhamos com a relação do profissional com um status de identidade jornalística.

Para se exercer uma profissão, é necessário que haja conhecimento especializado. No caso do emprego, não. A conceituação de emprego define saberes gerais que não precisam de grande esforço intelectual. F. Lopes (2007) avalia a identidade do jornalista de tal forma que

O papel de mediador que forma e educa está associado à suposição de que os jornalistas
detêm mais informaçôes e são mais capazes que as outras pessoas de chegar a percepçóes
politicamente racionais. Essa suposiçấo é inevitável, porque o exercício de uma função
educativa pressupóe uma vantagem educacional. Nesse sentido, encontramos aqui mais
uma importante representaçâo em torno da qual o jornalista constrói sua identidade:
a de intelectual (LOPES, 2007. p. 71).

A profissão está ligada ao conhecimento e à aplicação do saber profissional. Tanto que se exerce uma profissão; não se exerce um emprego. Um emprego se tem. Mesmo assim, os processos históricos podem convencionar saberes diversos em categorias específicas conferindo-lhes status de profissão.

Uma diferenciação entre profissão e emprego está no fato de que mesmo que a atividade seja remunerada, a busca do lucro náo é o objetivo maior na perspectiva profissional. Bourdon e Bourricaud (2000), ao definirem o termo 
profissão, exemplificam que um médico não pode escolher qual paciente atende ou não em funçáo do pagamento dos serviços prestados.

Os domínios de cada atividade na profissão são estipulados pela categoria profissional em associaçóes de classe, conselhos fiscalizadores da profissão, sindicatos, fóruns. Para Coelho (1999), a regulamentação profissional (graduação em nível superior) pressupóe, por lei, órgãos fiscalizadores, os Conselhos nacionais e regionais. Para a autora, a organização das profissões regulamentadas descansava em três pilares, cada qual com função diversa:

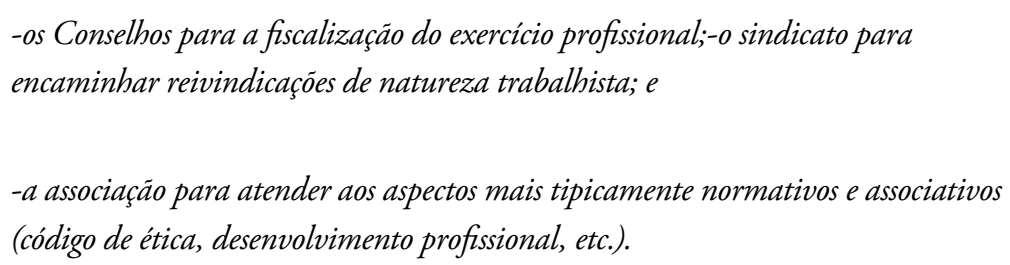

Travancas (1993, p. 67) afirma serem inúmeros os jornalistas que comparam a Medicina ao Jornalismo, pois "a medicina, tida como uma das mais nobres profissões, exige igualmente sacrifício e dedicação exclusiva”. Para a autora,

Os jornalistas estabelecem uma relaçâo com a ocupação que é bastante específica, não sendo partilhada por outros profissionais. Talvez um pouco como os médicos, como vários deles ressaltaram, o jornalismo como profissão exige de seus "eleitos" uma adesão (commitment) - termo utilizado pelo sociólogo norte-americano Howard Becker de tal ordem que impede muitas vezes que outras atividades ou setores de suas vidas tenham maiores dimensöes (TRAVANCAS, 1993 p. 13)

Travancas (1993, p. 71) pontua que tanto o médico quanto o jornalista têm uma relação passional com a profissão que exercem. Para a autora, a escolha da carreira implica em um nível de adesão que as conseqüências do labor refletiriam na vida privada. "É como se a profissão, no caso do jornalismo, já se tornasse uma característica própria e, portanto, inseparável do seu eu”.

Bourdon e Bourricaud (2000) afirmam que as profissóes, de modo geral, reivindicam certa autonomia na divisão de trabalho, em relação à hierarquia administrativa. Alguns exemplos seriam os advogados que não precisam prestar informaçóes sobre seus clientes em investigaçóes (preservando-os de incriminaçôes), assim como os jornalistas que não são obrigados a revelar suas fontes de informação. Essa autonomia frequentemente é postulada em acordos de categoria (convençóes coletivas, códigos de ética).

\section{Tipologias}

Lattman-Weltman (1992) estabelece tipologias sobre o jornalista como profissional ou empregado. Não são exaustivas e muitos menos universais. Trata-se apenas de tipologias destinadas à visualização da diversidade de 
identidades profissionais ${ }^{4}$. Utilizaremos os tipos como um mapa, no qual os atores (no caso, os jornalistas) podem transitar: Empregado como jornalista (1); Jornalista em crise (2); Repórter Engajado (3); Profissional da notícia (4); O que veste a camisa (5); Homem de Imprensa (6); e Em fim de carrei$r \boldsymbol{a}$ (7). Sendo todas referenciadas pelo mesmo autor.

A identidade Empregado como jornalista (1) valoriza a ocupação como emprego, uma fonte de remuneraçáo material básica, num ramo profissional pelo qual se sentiria atraído em função do gosto previamente adquirido pela escrita. Lattman-Weltman (1992) postula que este perfil apresentaria uma trajetória vocacional errática com experiências anteriores em atividades próximas ao labor jornalístico. E que este jornalista não se sentiria muito comprometido com a "profissão" e sua auto-imagem e seus ideais (isenção, objetividade, utilidade pública etc). Demonstraria acreditar que tais ideais deveriam nortear toda a prática jornalística, porém, de certo modo, se sentiria descompromissado em segui-los e em defendê-los, mais fielmente. Demonstraria um apego menor pela "carreira" não só porque a ascensão nas hierarquias implicaria em custos (encargos, responsabilidades, aumento da extensão e da intensidade da jornada de trabalho etc) que muitas vezes não corresponderiam a ganhos materiais proporcionais, mas também porque a subida provavelmente implicaria em um maior comprometimento com a empresa. Somando-se o fato de:

-[o jornalista] tenderia a avaliar certas condiçóes de trabalho positivamente (a existência de horário flexivel e pouco pesado, espaço para iniciativas e decisóes, grua médiolbaixo de formalização de tarefas etc);

- Optaria por lotaçóes em editorias pouco prestigiadas e se sentiria praticamente ignorado pela empresa, o que náo seria uma sensação vivenciada de modo ressentido; o desinteresse seria recíproco;

-Consideraria a remuneração baixa, mas suficiente (ao menos de acordo com o estágio atual de seus projetos de vida);

-Manifestaria criticamente à hierarquia da empresa suas materializaçôes eventuais com relaçâa ao controle técnico-ideológico sem se mostrar muito incomodado com isso;

-Não teria planos definidos quanto ao seu futuro na empresa ou na profissáo; tanto poderia sair (se recebesse uma proposta mesmo sendo pouco notado pelo mercado de trabalho por não se esforçar muito no labor cotidiano);

-Seria o profissional dominado por uma espécie de ceticismo tendendo a incorporar uma atitude de distanciamento e não comprometimento, seja com a empresa, seja com a identidade profissional de Jornalista (LATTMAN-WELTMAN, 1992, p. 72-74).

A identidade Jornalista em crise (2) está associada ao perfil do profissional cuja orientação privilegiaria o caráter de profissão de sua ocupação, ou seja, o comprometimento com a ideia de ser um jornalista: dotado de um conhecimento empírico e de competências específicas com aptidão ao desempenho de 
uma tarefa de algum modo necessária à sociedade. Lattman-Weltman (1992) entende que a insatisfação pessoal fundamenta este tipo. Há a presença de muitos conflitos ideológicos que instauram uma crise existencial. O problema é com a estrutura institucional dentro da qual trabalha. Para o autor, este perfil apresentaria, em segundo plano, certa valorização da ocupação enquanto uma "carreira", subordinada, no entanto, à orientação prevalescente da "profissáo", de modo que a carreira em questão poderia ser até muito bem vista e desejada, desde que construída em conformidade com o ideário do profissional jornalístico. O "emprego", como jornalista, em si mesmo, seria relativamente muito pouco valorizado. O resultado concreto do trabalho, tanto em termos estritamente técnicos, quanto em termos ideológicos, seria o critério decisivo para uma avaliação, seja esta positiva ou não, das condiçóes de trabalho; de tal sorte que qualquer um de seus aspectos concretos (jornada de trabalho, graus de autonomia etc) seria basicamente avaliado em função do produto final, ou seja, más condiçôes poderiam ser consideradas até como pouco relevantes ou incômodas se o produto for considerado bom, e vice-versa. Daí que condiçóes de trabalho adversas podem até ser citadas com uma ponta de orgulho, se o resultado do esforço for considerado positivo. Ainda como característica, o autor destaca que

- [o jornalista] se sentiria desprestigiado pela empresa; em termos pessoais ou por situarse numa editoria desprestigiada. Tal desprestígio seria vivenciado de forma ressentida, seja por considerar o produto do próprio trabalho como digno de maior consideração, seja em função de uma ideia a respeito do próprio potencial, que náo estaria sendo explorado convenientemente; se sentiria subestimado;

- O salário seria considerado baixo e até mesmo indigno, seja frente à responsabilidade social da profissão, seja no que respeita ao nivel sócio-cultural em que se situaria, numa espécie de hierarquia social informal;

-Não pretenderia continuar indefinidamente na empresa, mas, a rigor, não teria grandes perspectivas; ficando, provavelmente gostaria de manter-se na função atual, mas com outra situação de prestígio e salário (o que poderia implicar, por exemplo, na saida de uma editoria pouco prestigiada); saindo, as possibilidades de saida da imprensa, para um área próxima (LATTMAN-WELTMAN, 1992, p. 75-77)

A identidade Repórter Engajado (3) trata de um jovem profissional, tanto na idade quanto na experiência de trabalho da área. Lattman-Weltman (1992, p. 79) o chama de "romântico repórter", em pleno processo de construçáo da carreira. Há uma distinção entre o "engajado" e o "em crise" no sentido da autoconfiança. Para o autor, este perfil considera sua ocupaçáo primordialmente como "profissão", assim como o tipo "em crise". E na seqüência viriam o sentido de "carreira" e "emprego". Por ter uma inserção de cunho profissional, poderia evoluir para um engajamento mais especificamente político e/ou partidário, pois o repórter estaria comprometido, acima de tudo, com os ideais de serviço da profissão, e com o seu labor característico, tal como o senso comum e os estereótipos o traçam (o espectador privilegiado da história, olhos e ouvido do público etc). Este é o fato que leva este jornalista a ser um típico repórter. Para ele, uma carreira de sucesso seria bem-vinda e desejada; desde que não pusesse em jogo a 
imagem do profissional comprometido antes de tudo com a notícia (e não com uma empresa, por exemplo), não sendo a atividade um simples emprego. As condiçôes de trabalho seriam enfatizadas mais negativamente e confrontadas com os ideais de serviço da profissão que teriam forte apelo na auto-identidade. Desse modo, o fato destes "repórteres" geralmente trabalharem em editorias cujo peso e prestígio seriam consideráveis faria com que os controles técnicos e ideológicos fossem mais rigorosos e que a questáo de isenção se colocasse mais dramaticamente, favorecendo o aparecimento de crises éticas e de confrontos com a hierarquia e a linha do jornal. O autor ainda caracteriza que

- [o jornalista] consideraria injusta no julgamento que faz de seu trabalho; reconheceria a existência de manifestaçôes de apreço (elogios, indicaçôes para tarefas mais prestigiadas etc) por parte de superiores imediatos. Mas se ressentiria da ausência de uma efetivação deste apreço em termos de salário, que seria considerado relativamente baixo;

- Optaria por lotaçôes em editorias diversas, com niveis distintos de prestígio na redação, mas sempre com algum prestígio;

- Não faria planos de continuar na empresa. E nem no ramo. O comprometimento com o "ser jornalista" e com os ideais de serviço da profissão não se arrefeceriam. Persistiria o desejo de fazer um bom trabalho, um trabalho útil, nos moldes preconizados pelo ideário jornalistico (LATTMAN-WELTMAN, 1992, p. 77-80)

A identidade Profissional da notícia (4) contempla um perfil muito particular de equilíbrio e estabilidade. Lattman-Weltman (1992, p. 81-82) entende que o comprometimento desse jornalista com os ideais do jornalismo seria acompanhado pela noção de que tais ideias só poderiam ser postos em prática numa estrutura maior de grande redação. A primeira noção de relação com o labor é a de emprego. Acredita na profissão e na carreira como subsidiadas pelo exercício do ofício em uma empresa jornalística. Para o autor, quem se enquadra nesta tipologia tem o caráter subordinado da orientaçáo para a carreira e deve ser compreendido não como ausência de interesse ou ambição, mas sim como sinal do apego e da valorização que este tipo demonstraria com relação ao seu ofício, em conjunção com a satisfação e o conforto manifestado em relação à sua situação atual (seus níveis de prestígio, de remuneração, seus encargos e responsabilidades específicos e limitados da rotina de trabalho). Este tipo teria uma situação confortável, se sentindo, ao menos, razoavelmente prestigiado, seja em termos pessoais ou através de sua editoria. E com uma remuneração que mesmo se considerada baixa, em termos absolutos, não o seria em termos relativos. A auto-avaliação de sua situação seria sempre mediada pelo simples fato, em si mesmo já positivo, de estar devidamente empregado no seu reduzido mercado de trabalho e numa grande e importante redação (de modo que somente uma alteração dramática dos referenciais prestígio/remuneraçáo e de seus conteúdos seria capaz de romper com este estado de relativa harmonia). Somada, ainda, sua perspectiva, não muito definida, seria a de continuar na empresa. Aumentos e promoções seriam bem-vindos, inclusive com aumento das atribuiçôes e responsabilidades, desde que não implicassem 
numa alteração drástica da rotina de trabalho que viesse a impedir ou sacrificar atividades desempenhadas com satisfação.

A identidade $\boldsymbol{O}$ que veste a camisa (5) é mais engajada no sentido profissional que o seu anterior Profissional da notícia (4). A ideia de carreira é mais valorizada, mas ainda subsidiária do emprego. Algumas concessôes no âmbito organizacional em detrimento de concepções pessoais não seriam obstáculos no trabalho. Desta forma, o sucesso profissional é projetado como o norte. O mercado de trabalho interno (a instituição) é mais importante do que o externo (outras empresas e a categoria jornalística). Lattman-Weltman (1992, p. 84) indica que esse jornalista tem como limite o céu, desde que "seja um céu acessível (num prazo não muito longo) e iluminado pelas constelaçóes específicas do "metier jornalístico". O autor destaca que por vestir a camisa da empresa simplesmente não se distingue dos demais colegas de trabalho. Por isso, investe num sentimento de responsabilidade para com o jornal, como também, de cumplicidade, de comunhão entre seus interesses e os da estrutura que o emprega. A ênfase na carreira está em segundo plano. Em primeiro está a noção de emprego de modo a conformar um padráo de comprometimento com a empresa que deixa a profissão em uma posição relativamente marginal e pouco relevante, de tal ordem que praticamente não se poderia nem mesmo pensar a possibilidade deste profissional vivenciar o que chamamos de uma crise ética. Também existe a necessidade de realizar um produto jornalístico sempre melhor. Este "melhor" seria balizado em termos estritamente técnicos. Haveria um comprometimento regular não exatamente com os ideais da profissão, mas sim a traduçóes (e, consequentemente, a reduçôes) processuais destas, sob a forma de técnicas e/ou regras de objetividade jornalística. $\mathrm{O}$ autor ainda cita o fato de que

-De modo geral, este tipo se consideraria numa posição confortável nas hierarquias
formais e informais da redação. Considerar-se-ia prestigiado (sejam em termos pessoais,
seja pela função ou setor) e, principalmente, se veria numa trajetória ascendente de
carreira; - Evidentemente não só continuaria na empresa como também teria a intenção de subir (mesmo já estando no alto, a subida seria de caráter mais informal: mais prestígio, maior remuneraçâo, maior poder etc). Acreditaria realmente nesta possibilidade. $E$ claro que convites externos seriam bem recebidos (inclusive como instrumento de barganha e autovalorização pessoal) (LATTMAN-WELTMAN, 1992, p. 82-84).

A identidade Homem de Imprensa (6) valoriza a ocupação como sendo um estágio da carreira. Quer a ascensão na hierarquia da organização, mas é apegado mais à profissão do que ao emprego. Ao contrário da tipologia $\boldsymbol{O}$ que veste a camisa (5), o jornalista tem horizontes profissionais além do mercado de trabalho interno (instituição). Lattman-Weltman (1992, p. 85) postula que o emprego teria um caráter não tão relevante e mesmo até provisório em sua escala de valores. Seria apenas uma etapa, ou o momento atual de um "continuum": a carreira deste profissional da imprensa. Para o autor, mesmo 
exercendo cargo de confiança, assumindo responsabilidade, atribuiçóes de chefia (comprometendo-se com a estrutura de poder da empresa) este jornalista sempre procuraria preservar uma espécie de aura profissional, manifestada num discurso onde os ideais da profissão estariam sempre presentes, e consubstanciada num relativo grau de autonomia pessoal que lhe permitira não se sujeitar aos imperativos da instituição. $\mathrm{O}$ arranjo carreira/profissão pode ser visualizado melhor pelo fato de que os tipos Jornalista em crise (2) e Repórter Engajado (3) também avaliariam a sua situação profissional, mediada em função do resultado concreto de seu trabalho (assim como também não se importariam muito com as dificuldades e com o desgaste do dia a dia). Contudo, aqui, a avaliação do trabalho tenderia a incorporar também a avaliação do jornal como um todo, ou ao menos da editoria pela qual este profissional responderia, ou seja, haveria uma fusão maior entre o trabalho pessoal e o jornal (e não exatamente a empresa), em relação aos méritos técnicos da instituição. Tem-se como características ainda, o fato de que este perfil

-Seria um profissional que seguramente já teria um nome no mercado de trabalho
externo e que exerceria funçóes de prestígio; - A remuneração não seria exatamente um problema. O seu prestígio pessoal pode lhe garantir um salário relativamente bom;

-Justificaria a existência de uma hierarquia da redação em função dos chamados imperativos industriais (prazo e imposiçôes do parque gráfico e da publicidade) e da linha editorial do jornal (LATTMAN-WELTMAN, 1992, p. 84-87).

O último tipo descrito é a identidade $\boldsymbol{E} \boldsymbol{m}$ fim de carreira (7) cuja orientação privilegia o emprego como forma de remuneração material básica. Ao contrário do Empregado como Jornalista (1), tem como subsidiária a carreira e não o sentido de profissão. Lattman-Weltman (1992, p. 87-88) entende que o apego ao caráter emprego, nesse caso, seria inseparável de um alto grau de comprometimento com a empresa, que o mantém empregado no metier. Como não se trata de um profissional jovem (tanto em idade quanto em experiência) seria o oposto do Repórter Engajado (3). A situação deste profissional poderia ser definida como contendo basicamente uma única categoria definidora: o salário, que mesmo sendo, em certos casos, baixo, seria considerado relativamente bom (ao menos nas situaçóes mais desfavorecidas, frente à alternativa de uma aposentadoria). Para o autor, o prestígio pessoal não seria nunca muito grande, independentemente dos graus de prestígio específicos da função e/ou da editoria. à parte a intenção de, enquanto for possível e necessário, permanecer no emprego, as perspectivas (e pretensóes) desse jornalista seriam praticamente nulas.

Cada tipologia apresentada corresponde a um tipo-ideal. São arranjos determinados de hierarquização de categorias de orientação, o que parece-nos uma forma adequada para vislumbrar a relação do jornalista com o trabalho dentro das categorias emprego, profissão, carreira e ofício, da Sociologia. 


\section{Considerações finais}

Sabe-se que a profissão emerge de uma demanda social. A transformação de uma atividade geral em profissão específica é verificável na história. Tradicionalmente, em outros países, as atividades de jornal e notícia são privativas dos jornalistas. E o ofício, nas assessorias de imprensa, dos profissionais de Relaçôes Públicas (RPs). Contudo, no Brasil, há uma caracterização peculiar desse labor como sendo do jornalista. E, neste aspecto, até pela limitação de ser um artigo, não pudemos expor de maneira específica o caso brasileiro, no que tange ao processo de estruturaçáo da profissão de jornalista nas assessorias, tendo em vista a exposição somente na reportagem.

De forma breve, buscamos várias reflexôes sobre o trabalho jornalístico enquadrando-o em categorias bem tradicionais da Sociologia das Profissóes no intuito de discutir níveis de adesão ao ofício em jornalismo, ao referencial de conhecimento do labor, sua função social e história condensada. Resgatando autores brasileiros que já trabalharam questóes sociológicas e antropológicas bem densas em relação ao trabalho e à profissão de jornalista, dentre os quais citam-se: Folquening (2002), Lattman-Weltman (1992), Paccola (2003), Ribeiro (1994), Travancas (1993). Essa contribuição sobre a relação do jornalista com o trabalho dentro das categorias emprego, profissão, carreira e ofício, da Sociologia das Profissóes, parte do nosso esforço de trazer para os estudos de Newsmaking e para o bojo da ciência em Comunicação tensôes, incoerências e problemáticas inerentes ao jornalismo, mas pouco abordadas. No Brasil, comum é termos contato com toda a discussão sobre a adesão de jornalistas ao trabalho no tocante aos postos de trabalho das redaçóes ou das assessorias. E, no entanto, existem outras questôes a serem trabalhadas sobre a adesão profissional. Nosso breve panorama não esgota a discussão, mas traz reflexóes para este cenário com intuito de fomentar este tipo de enfoque na comunidade acadêmica.

\section{Referências Bibliográficas}

BOURDIEU, Pierre. A economia das trocas simbólicas. São Paulo: Perspectiva, 1998.

FREIDSON, Eliot. Para uma análise comparada das profissóes: a institucionalização do discurso e do conhecimento formais, in: Revista Brasileira de Ciências Sociais, ANPOCS, SP, n. 31, junho 1996.

LATTMAN-WELTMAN, Fernando. Jornalistas: agenciando a cidadania, publicizando o privado. Dissertação (Mestrado em Sociologia), UFRJ.1992.

LOPES, Fernanda. Auto-referenciação e construção da identidade jornalística. Dissertação (Mestrado em Comunicação), UFRJ. 2007.

MATTELART, Armand; MATTELART, Michele. História das teorias da comunicação. São Paulo: Loyola, 1999.

MENDES, Ricardo. As disputas no campo profissional do jornalismo.

Dissertação (Mestrado em Sociologia), UFSCAR. 1997. p. 17 
ORTEGA Y GASSET, José. A rebelião das massas. São Paulo: Martins Fontes, 2007.

PACCOLA, Carina. Um retrato de quem retrata o mundo: um estudo sobre a estruturação da prática profissional dos jornalistas. Dissertação (Mestrado em Sociologia), UEL. 2003

RIBEIRO, Jorge Claúdio. Sempre Alerta-condiçôes e contradiçôes do trabalho jornalistico. São Paulo, Olho d’Água/ Brasiliense, 1994.

STEINBERGER, Margarethe. A ética do jornalismo latino-americano na geopolitica da pós-modernidade. In DOWBOR, Ladilau; IANNI, Octávio; RESENDE, Paulo-Edgar A.; SILVA, Hélio (orgs.) Desafios da comunicação. Petrópolis. Vozes. 2000

STOQUE, Lucas. Tudo por uma paixão. Acesso em julho de 2012. Disponível em http://observatorio.ultimosegundo.ig.com.br/artigos/ da20042000.htm

TRAVANCAS, Isabel. O mundo dos jornalistas: um estudo antropológico sobre identidade e carreira em camadas médias. São Paulo. Summus. 1993.

WEbER, Max. A Ética Protestante e o Espírito do Capitalismo. 4 ed. São Paulo: Livraria Pioneira Editora, 1985.

\section{Notas}

1. Lei $\mathrm{n}^{\circ} 5.250$, de 9 de fevereiro de 1967 , conhecida como Lei da Imprensa.

2. As principais contribuições para a sociologia das profissões foram feitas por Weber, M. (Economie et societê); Durkheim, E. (A divisão do trabalho social e Lições de sociologia: a moral, o direito e o estado); e Parsons, T. (The social system e The professional and social structure)

3. Alguns autores preferem os termos "ofício" e "ocupação" ao invés de "emprego".

4. "Cada tipo deve ser compreendido como um 'constructo' teoricamente coerente (e, portanto, forçosamente arbitrário, mesmo que minimamente) de identidades profissionais que se inserem relacionalmente num mesmo campo social determinado; quer dizer: cada tipo compartilha, como os outros, de certas características definidoras, distinguindo-se de todos, porém pelo arranjo específico que apresenta de tais características" (LATTMAN-WELTMAN, 1992, p. 69) 